\title{
Chemical and biological effects of some mixtures of plant oils and Thymus vulgaris on liver diseases
}

\author{
Samah M. Ismael ${ }^{1}$, Abour M. Abdelrahman ${ }^{1}$, Eman A. Sultan $^{2}$ and \\ Shaimaa M. Omran ${ }^{1}$
}

1- Home Economic Dept., Faculty of Specific Education, Ain Shams Univ., Cairo, Egypt

2- Endocrinology and Metabolism Department, National Nutrition Institute, Egypt

Received: August 3, 2020; Accepted: September 12 2020; Available Online November 25, 2020

\begin{abstract}
Liver is the vital organ with a wide range of functions that can influence other body organs. Dietary components are essential for the healthy or diseased liver. Selected food plants can provide nutritional and medicinal support for liver diseases. Herbal and oil medicinal products are increasingly being used and many of them have shown promising potential for the treatment of liver diseases. The aim of this study is to investigate the protective role of thyme, olive oil and flaxseed oil on carbon tetrachloride $\mathrm{CCl}_{4}$ induced changes in liver enzymes of albino rats.

Sixty adult male Albino rats weighing about $130 \pm 5 \mathrm{~g}$ were taken and divided into twelve groups, each with five rats. The first group is the control (-) and fed on normal diet for 10 weeks. The second group received subcutaneous injection with $\mathrm{CCL}_{4}$ in paraffin oil $(50 \%$ $\mathrm{v} / \mathrm{v} 2 \mathrm{ml} / \mathrm{kg}$ ) twice per week for 2 weeks to induce chronic damage in the liver tissue and fed on normal diet (control +$)$. Another experimental groups $(n=5 /$ group $)$ were fed a Commercial diet with different doses from thyme, flaxseed oil and olive oil for 10 weeks.

There were a significant increase in the activities of serum ALT and AST in rats of the positive control group (+) as compared to negative control group $(-)(\mathrm{P} \leq 0.05)$. While the protected groups with high doses of thyme $(4,6,8,10,12)$ and olive oil and flaxseed oil $(3,5,7,9,11)$ recorded a significant decreased serum AST and ALT enzyme compared to the low doses groups.

Recommendations and Conclusion: High doses of thyme, olive oil and flaxseed oil could ameliorate carbon tetrachloride (CCl4)-induced liver injury in rats, which. Suggesting that diet rich in flaxseed oil, olive oil and thyme might be a promising approach for prevention of liver diseases.
\end{abstract}

Keyword: Thyme, Olive oil, Flaxseed oil, $\mathrm{CCL}_{4}$, Albino rats, Liver enzymes, Kidney functions, Lipid Profile.

\section{INTRODUCTION}

Liver plays an important role in vital process of body including metabolism of fat, carbohydrates, and proteins, filtration of microbes, viruses, endotoxins, and antigens, storage of glycogen, vitamins, and minerals, synthesis of clotting factors and albumin, secretion of bilirubin and detoxification of drugs and hormones (Gan et al., 2011). Excess dietary fat and increased insulin glucose level will increase fatty acids in liver and triglycerides leading to steatosis NASH Non alcoholic steatohepatitis (Balkhy et al., 2016). Liver has a remarkable capacity to adapt to injury through tissue repair, where the multifaceted interactions of immune cell subsets regulate this repair process, such that fibrosis and wound healing can be considered as part of the innate immune response to tissue damage (Farooq et al., 2015). 
Samah M. Ismael et al.

The most frequent form of liver disease is chronic hepatitis which is defined as a hepatic inflammation that lasts more than 6 months. Hepatitis commonly occurs with hepatitis $\mathrm{B}$ and $\mathrm{C}$ infections, autoimmune hepatitis, alcoholic and nonalcoholic steatohepatitis, primary biliary cirrhosis, primary sclerosing cholangitis, metabolic causes such as hemochromatosis and Wilson's disease (Ivanova et al., 2017).

About $6 \%$ of the world population are chronically infected by the hepatitis (Paoulomi et al., 2012). Viral hepatitis caused 1.34 million deaths in 2015 WHO (2018). Recently great interest has been shifted towards the natural products as medical plants and Essential oils as compared to the classical or synthetic products due to their better affordability, acceptability and compatibility with the human physiology and minimal side effects (Lopez et al., 2017).

Plants food is an essential part of the human diet and comprises various compounds which are closely related to liver health. Selected food plants can provide nutritional and medicinal support for liver diseases (Lei et al., 2017). A vast majority of plants are now being used as phytomedicines. Natural remedies from traditional plants are seen as effective and safe alternative treatments for hepatotoxicity. Several studies have shown that hepatoprotective effects are associated with phyto-extracts/ phyto-compounds rich in natural antioxidants (Nayak et al., 2011). Many bioactive compounds and extracts from plants have thus been investigated for hepatoprotective and antioxidant effects against hepatotoxin induced liver damage (Yousef et al., 2010).

Olive oil is known for its health benefits. Diet patterns with higher intakes of olive oil are associated with a reduced risk of death from all causes (Al Badr, 2016). It decreases the serum triglycerides, normalizes the liver enzyme biomarkers and significantly reduces the fat droplet accumulation in liver by suppressing the inflammation and restoring the abnormal lipid metabolisms (Wani et al., 2015).

Flaxseed oil (Linum usitatissimum L.) has anti-inflammatory activity with a promising functional food ingredient. Flaxseed oil at different replacement levels resulted in significant improved in lipids profile, liver and kidney. Thymus vulgaris L use for treating symptoms of bronchitis, whooping cough and catarrh of the upper respiratory tract. Additional therapeutic properties of thyme include antioxidant (Aristatile et al., 2019) and antimicrobial activity, genotoxic, anti-inflammatory, analgesic and antipyretic effects and antidiabetic effects, among others. Several thyme preparations, such as dried herb, liquid extract, elixir, and tincture, are included in different official monographs, and they are commonly added to formulations involving multiple herbal constituents, most often to syrups, but may be also incorporated in tablets, thyme is to aid digestion of fatty foods (Pankaj et al., 2013).The hepatoprotective effects of thyme have been observed in several experimental models of liver injury. The ethanolic and methanolic extracts of thyme have been effective against aflatoxins- and $\mathrm{N}$-nitroso-diethylamine (NDEA)- induced oxidative liver damage. (Abdel-Aziem et al., 2014).Thyme extract and essential oil could ameliorate carbon tetrachloride $\left(\mathrm{CCl}_{4}\right)$ induced liver injury in rats . The protective effects of aqueous extract and essential oil obtained from thyme (Grespan et al., 2014).

\section{MATERIALS AND METHODS Materials}

Thymus vulgaris (L.) Burm, Family (lamiaceae) was obtained from the from local market in Cairo. Extra virgin Olive oil produced by Wadi food industries company .Flaxseed oil produced by Imtenan Health Shop. Kits for biochemical analysis were purchased from Gamma Trade for Company Pharmaceutical and Chemicals, Dokki, Giza. Carbon 


\section{Chemical and biological effects of some mixtures of plant oils and Thymus vulgaris on liver diseases}

tetrachloride $\mathrm{CCl} 4$ (a colorless nonflammable liquid, of molecular weight 153: 84 and freshly diluted in paraffin oil (1:1) volume to a final concentration before use) was obtained from SigmaAldrich (SPSS, 1998, London, UK).

\section{Methods}

Moisture, protein, lipid, ash and fiber were determined according the method of AOAC (2000). The total carbohydrate contents were tested quantitatively according to (Kostas et al., (2016). Determination of the antioxidative capacity is performed by the reaction of antioxidants in the sample with a defined amount of exogenously provide hydrogen peroxide $\left(\mathrm{H}_{2} \mathrm{O}_{2}\right)$ The antioxidants in the sample eliminate a certain amount of the provided hydrogen peroxide. The residual $\mathrm{H}_{2} \mathrm{O}_{2}$ is determined colorimetrically by an enzymatic reaction which evolves the conversion of 3,5, dichloro -2- hydroxy benzenesulphonate to a colored product (Chen el al., 2010). Fatty acids in thyme, olive oil and flaxseed oil were identified and quantified in examined formulations by GC/MS (Kaur et al., 2017).

\section{Biological experiment}

\section{Animal, housing and diets:}

Sixty male Albino rats weighing about $170 \pm 5 \mathrm{~g}$ were obtained from the Agricultural Research Center, Giza, Egypt. The animal groups were kept in an atmosphere of filtered, pathogen-free air and water and maintained at a temperature between $20-25^{\circ} \mathrm{C}$ with a $12 \mathrm{~h} \mathrm{light/dark}$ cycle and light cycle (8-20 h) and relative humidity of $50 \%$. The animals acclimatized for one week as an adaptation period. The animals were randomly divided into twelve groups of Five rats.

each. The first group of rats, the control (-) fed on commercial diet (Table 1) for 10 weeks (total period of experimental). The second groups was subcutaneous injected with CCL4 in paraffin oil $(50 \%$ v/v 2 $\mathrm{ml} / \mathrm{kg}$ ) twice per week by subcutaneous injection for 2 weeks to induce chronic damage in their liver tissue (Jayasekhar et al., 1997) with fed on commercial diet $($ control +) as seen in Table (1).

-The other groups were injected with $\mathrm{CCL}_{4}$ in paraffin oil $(50 \% \mathrm{v} / \mathrm{v} 2 \mathrm{ml} / \mathrm{kg})$ twice per week by subcutaneous injection for 2 weeks.

- The third and fourth groups fed on commercial diet + thyme $(10 \%$ and $15 \%$ in substitution of fiber). The fifth and sixth groups fed on commercial diet + Olive oil (7 and $14 \mathrm{mg} / \mathrm{rat} /$ daily).

-The seventh and eighth groups fed on Commercial diet + Flaxseed oil (7 and 14 $\mathrm{mg} / \mathrm{rat} /$ daily).

The ninth group feds on Commercial diet +Thyme $(10 \% /$ rat/daily $) \&$ olive oil (7mg/rat/daily).

-The tenth group fed on commercial diet + Thyme (15\%/rat/daily) \& olive oil (14 $\mathrm{mg} / \mathrm{rat} /$ daily).

-The eleventh group fed on commercial diet + Thyme (10\%/rat/daily) \& Flaxseed oil ( $7 \mathrm{mg} / \mathrm{rat} /$ daily).

-The twelfth group fed on commercial diet + Thyme $(15 \% /$ rat/daily) \& Flaxseed oil (14 mg/rat/daily in Table (2)

The following steps by Schermer (1967) were done in rats after ten weeks of treatment in each group.

* The animals were fasted for $12 \mathrm{~h}$.

* Blood samples were withdrawn from orbital plexus venous by using fine capillary glass tubes.

* Blood samples were collected into plain tubes without anticoagulant and allowed to clot.

* Blood samples were centrifuged at 3000 rpm for $10 \mathrm{~min}$ at $4^{\circ} \mathrm{C}$, to obtain clear serum.

* Serum was frozen at $-18^{\circ} \mathrm{C}$ until analyzed.

* Animals were anesthetized with ether and sacrificed.

* They were quickly dissected to excise the liver, kidney, spleen and heart.

* These organs were weighed and then kept until histological investigations. 

Table (1): Composition of commercial diet.

\begin{tabular}{ll}
\hline Ingredients & Percentage \% \\
\hline Protein:[soy flour meal+ sun flower meal + gluten] & 21.00 \\
Fat & 03.26 \\
Crude fiber & 03.29 \\
Dl. Methionine & 00.40 \\
Vitamins mixed & 01.00 \\
Minerals mixed & 04.00 \\
Carbohydrates & 67.05 \\
\hline
\end{tabular}

Table (2): Experimental diets.

\begin{tabular}{|c|c|}
\hline Groups & Experimental diets \\
\hline Frist & Commercial diet (control (-) group) \\
\hline Second & $\mathrm{CCL}_{4}+$ Commercial diet (control (+) group) \\
\hline Third & $\left(\mathrm{CCL}_{4}+\right.$ Commercial diet $)+($ Thyme $(10 \%$ in substitution of fiber $)$. \\
\hline Fourth & $\left(\mathrm{CCL}_{4}+\right.$ Commercial diet $)+($ Thyme $(15 \%$ in substitution of fiber $)$. \\
\hline Fifth & $\left(\mathrm{CCL}_{4}+\right.$ Commercial diet $)+($ Olive oil $(7 \mathrm{mg} / \mathrm{rat} /$ daily $)$ \\
\hline Sixth & $\left(\mathrm{CCL}_{4}+\right.$ Commercial diet + Olive oil (14 mg/rat/ daily) \\
\hline Seventh & (Commercial diet + Flaxseed oil $(7 \mathrm{mg} / \mathrm{rat} /$ daily $)+\mathrm{CCL}_{4}$ \\
\hline Eighth & $\left(\right.$ Commercial diet + Flaxseed oil $(14 \mathrm{mg} / \mathrm{rat} /$ daily $)+\mathrm{CCL}_{4}$ \\
\hline Ninth & $($ Commercial diet + Thyme $(10 \% /$ rat/daily $) \&$ olive oil $(7 \mathrm{mg} / \mathrm{rat} /$ daily $))+\mathrm{CCL}_{4}$ \\
\hline Eighth & $($ Commercial diet + Thyme $(15 \% /$ rat/daily $) \&$ olive oil $(14 \mathrm{mg} / \mathrm{rat} /$ daily $))+\mathrm{CCL}_{4}$ \\
\hline Tenth & $\left(\right.$ Commercial diet + Thyme $(10 \% /$ rat/daily $) \&$ Flaxseed oil $(7 \mathrm{mg} / \mathrm{rat} /$ daily $)+\mathrm{CCL}_{4}$ \\
\hline Twelfth & (Commercial diet + Thyme $(15 \% /$ rat $/$ daily $)$ \& Flaxseed oil $(14 \mathrm{mg} / \mathrm{rat} /$ daily $)+\mathrm{CCL}_{4}$ \\
\hline
\end{tabular}

\section{Histopathology Technique}

The tissue sample from liver were fixed immediately after dissection in $10 \%$ neutral formalin for $24 \mathrm{~h}$, then collected and dehydrated using ascending grades of alcohol, cleaned in xyline and embedded in paraffin wax. Tissues were sectioned at a thickness of 3 micron and stained with hematoxylin and eosin stains (Banchroft $e t$ al., 1996). Then examined by the light microscope for detection of any histopathological alteration.

\section{Biological Determination}

Biological evaluation of the different tested diets was carried by determination of food intake (FI), body weight gain\% (BWG \%) and organs weight/body weight $\%$ according to Chapman et al. (1959).

BWG $\%=[($ Final weight-Initial weight $) /$ (Initial weight)] X 100

Organ weight/ body weight $\%=($ Organ weight / Final weight) X 100

\section{Biochemical analysis}

Blood samples were withdrawn from orbital plexus venous by using fine capillary glass tubes, placed in centrifuge tubes without anticoagulant and allowed to clot. After the serum prepared by centrifugation (3000 rpm for $15 \mathrm{~min}$ ), serum samples were analyzed by biodiagnostic kits.

Serum (uric acid, urea nitrogen and creatinine) were measured colorimetrically using spectrophotometer (model DU 4700) adjusted at $510 \mathrm{~nm}, 550$ $\mathrm{nm}$ and $510 \mathrm{~nm}$, respectively by (Barham. (1972) and (Fossati et al. 1980), respectively.

Alanine aminotransferase (ALT) and aspartate aminotransferase (AST) activities were determined colorimetrically using spectrophotometer (model DU 4700) at $505 \mathrm{~nm}$ according to the method of (Tietz.,1990). Serum cholesterol and triglycerides concentrations were determined according to Tietz (1990) 
Chemical and biological effects of some mixtures of plant oils and Thymus vulgaris on liver diseases

and Vassalt et al. (1986) using spectrophotometer (model DU 4700) at $546 \mathrm{~nm}$ and $500-550 \mathrm{~nm}$, respectively.

Lipoprotein (HDL-C and LDL-C) was determined by Fossati and Principe (1982) and Watson (1960) using spectrophotometer (model DU 4700).

\section{Statistical Analysis}

The obtained data were exposed to analysis of variance. Duncan's multiple range test at 5\% level of significance was used to compare between means. The analysis was carried out using the PROC ANOVA procedure of Statistical Analysis System (SAS, 2006).

\section{RESULTS AND DISCUSSION}

Physicochemical analyses of Thyme, Olive oil and Flaxseed oil
The proximate composition of thyme, olive oil and flaxseed oil are shown in Table (3). The results of thyme revealed that moisture; carbohydrate, protein, fat, fiber and ash were 17.87, 25.85, 5.80, $1.45,15.18$ and $2.93 \%$. Thyme powder showed an increase in protein, carbohydrate, crude fiber, ash and fat and decrease in moisture. While, the total fat in olive oil and flaxseed oil were $99.66 \%$ and $99.58 \%$, respectively. Thyme constituents of minerals were potassium $(590 \%)$, sodium $(7 \%)$, calcium $(387 \%)$, iron (15.6\%). Nawal (2011) mentioned that dry thyme was particularly rich in iron. Iron intake and total iron absorption were highest for the rats fed the dry thyme diet. In the present study the composition of thyme powder presents $17.87 \%$ water $5.80 \%$ protein, $1.45 \%$ fat and $2.93 \%$ ash.

Table (3): Chemical constituent of Thyme, Olive oil and Flaxseed oil.

\begin{tabular}{|l|l|l|l|}
\hline \multirow{2}{*}{$\begin{array}{l}\text { Constituents } \\
\text { Percentage (\%) }\end{array}$} & \multicolumn{3}{|c|}{ Treatments g/100g } \\
\cline { 2 - 4 } Moisture & Thyme & Olive oil & Flaxseed oil \\
\hline Carbohydrate & $17.87 \pm 0.73^{\mathrm{B}}$ & 0 & 0 \\
\hline Protein & $25.85 \pm 0.19^{\mathrm{C}}$ & 0 & 0 \\
\hline Fat & $5.80 \pm 0.27^{\mathrm{B}}$ & 0 & 0 \\
\hline Fibre & $1.45 \pm 0.22^{\mathrm{C}}$ & $99.66 \pm 0.19^{\mathrm{A}}$ & $99.58 \pm 0.48^{\mathrm{A}}$ \\
\hline Ash & $15.18 \pm 0.73^{\mathrm{B}}$ & 0 & 0 \\
\hline pH & $2.93 \pm 0.47^{\mathrm{B}}$ & 0 & 0 \\
\hline
\end{tabular}

* Data are presented as means $\pm \operatorname{SDM}(n=3)$.

A, B, C: Means with different letter among treatments in the same rows are significantly different.

\section{Antioxidants:}

Antioxidants are component of plant foods play an important role in the treatment of diseases. The obtained results of total antioxidant activity DPPH 2,2Diphenyl-1-picrylhydrazyl (DPPH) were Olive oil $7.23 \%$, flaxseed oil $12.02 \%$ and Thyme $96.31 \%$ (Table 4).

Thyme was the highest percentage compared to olive oil and flaxseed oil as shown in Table (4). Antioxidant activity of thyme was reported to be derived mostly

from the presence of phenolic compounds, particularly thymol and carvacrol, as the major phenolic active compounds of thyme, were identified and quantified in examined thyme formulations by GC/MS (Kaur et al .,2017). Found that thymol concentrations of $75.52[\mathrm{mu}] \mathrm{g} / \mathrm{ml}$, respectively. Concentrations of carvacrol were much lower than those of thymol in , and they were $0.36 \quad[\mathrm{mu}] \mathrm{g} / \mathrm{ml}$. Accumulation of phenolic compounds may be affected by many factors, such as genetic background, pedoclimatic conditions and agronomic practices. 
Table (4): Test result of Antioxidant activity DPPH \%

\begin{tabular}{|l|l|l|l|}
\hline \multirow{2}{*}{ Antioxidant } & \multicolumn{3}{|l|}{ activity DPPH \% } \\
\cline { 2 - 4 } & Thyme & Olive oil & Flaxseed oil \\
\hline DPPH \% & 96.31 & 7.23 & 12.02 \\
\hline
\end{tabular}

Recently, there is a growing interest in phenolic compounds, and flavonoids in particularly because of their antioxidant capacity and possible benefits in food and pharmaceutical applications and in human health. Plants have been used for treatment of many diseases (Gülçin et al., 2017). Phenolic compounds are the most widely occurring chemicals, which having strong antioxidant properties (Topal et al., 2018).

Paoulomi et al. (2012) found that the type and amount of various antioxidants in flaxseed oil exhibit their antioxidant activity due to their redox property. Measurement of antioxidant activity in olive oil was performed by determination of total antioxidant activity, polyphenol and flavonoid. Gan et al. (2011) found that the total phenolic concentration can be improved by extracting oil from destined olives. On the contrary, no effect of destining on olive oil quality, as measured by acidity, peroxide number, spectrophotometric indices, phenolics, and volatiles. As documented by these studies, destining had no influence on the fatty acid and sterol composition of olive oil.

Biological evaluation of thyme, olive oil and flaxseed oil on experimental rats: General signs in the rats

No rats among groups died during the experimental period (10 weeks) and all rats groups exhibited no abnormal signs throughout the test period

Body and organs weight gain of experimental rats fed on different ratios of Aloe vera gel

The final body weights (FBW) of rats for different groups are given in Table (4). There were significant differences $(\mathrm{P} \leq 0.05)$ in the final body weights of rats in the control (-). The same trend was noticed in the BWG in protected group.

Table (4). Mean body weight gain (g) of rats fed on different ratios of thyme, olive oil and flaxseed oil

\begin{tabular}{|c|c|c|c|c|c|c|c|c|}
\hline \multirow{2}{*}{$\begin{array}{l}\text { Body } \\
\text { weight } \\
\text { (g) } \\
\end{array}$} & \multirow{2}{*}{ Control (-) } & \multirow{2}{*}{ Control (+) } & \multicolumn{2}{|l|}{ Thyme } & \multicolumn{2}{|l|}{ Olive oil } & \multicolumn{2}{|l|}{ Flaxseed oil } \\
\hline & & & Group (3) & Group (4) & Group (5) & Group (6) & Group (7) & Group (8) \\
\hline IBW & $123.00 \pm 2^{\mathrm{a}}$ & $125.00 \pm 3.1^{\mathrm{a}}$ & $124.30 \pm 4.0^{\mathrm{a}}$ & $123.91 \pm 5.8^{\mathrm{a}}$ & $123.6 \pm 16.8^{\mathrm{c}}$ & $126.0 \pm 6.2^{\mathrm{b}}$ & $126.0 \pm 6.2^{\mathrm{b}}$ & $121.4 \pm 17.8^{\mathrm{c}}$ \\
\hline $14 \mathrm{~d}$ & $129.04 \pm 2.4^{\mathrm{ba}}$ & $134.33 \pm 4.5^{\mathrm{a}}$ & $128.51 \pm 4.6^{\mathrm{ba}}$ & $126.91 \pm 5.8^{\mathrm{ba}}$ & $128.79 \pm 2.7^{b}$ & $131.79 \pm 5.3^{\mathrm{a}}$ & $133.79 \pm 5.34^{\mathrm{a}}$ & $127.59 \pm 2.7^{b}$ \\
\hline $28 \mathrm{~d}$ & $138.28 \pm 4^{\mathrm{a}}$ & $140.54 \pm 4.5^{\mathrm{a}}$ & $132.98 \pm 3.5^{\mathrm{b}}$ & $130.63 \pm 10.9^{b}$ & $134.31 \pm 3.4^{\mathrm{b}}$ & $137.27 \pm 8.6^{b}$ & $144.71 \pm 9.11^{\mathrm{a}}$ & $137.67 \pm 6.6^{\mathrm{b}}$ \\
\hline $56 d$ & $145.19 \pm 5.5^{\mathrm{b}}$ & $148.06 \pm 5.9^{\mathrm{a}}$ & $144.85 \pm 4.8^{b}$ & $140.38 \pm 9.2^{c}$ & $151.70 \pm 3.4^{\mathrm{a}}$ & $147.88 \pm 4.4^{\mathrm{ba}}$ & $152.70 \pm 3.44^{\mathrm{a}}$ & $149.58 \pm 3.4^{\mathrm{ba}}$ \\
\hline 70d & $166.36 \pm 6.2^{\mathrm{a}}$ & $151.58 \pm 7.7^{\mathrm{c}}$ & $162.26 \pm 5.1^{\mathrm{b}}$ & $158.81 \pm 4.4^{\mathrm{b}}$ & $158.22 \pm 19.7^{b}$ & $164.90 \pm 7.49^{\text {ba }}$ & $158.22 \pm 19.72^{\mathrm{b}}$ & $151.58 \pm 10.5^{\mathrm{b}}$ \\
\hline FBW & $175.80 \pm 22^{\mathbf{b}}$ & $155.0 \pm 21.7^{\mathrm{c}}$ & $176.30 \pm 5.3^{\mathrm{b}}$ & $166.10 \pm 7.1^{\mathrm{ab}}$ & $162.30 \pm 20.7^{b}$ & $170.00 \pm 7.8^{\mathrm{ab}}$ & $164.90 \pm 7.49^{\text {ba }}$ & $160.30 \pm 20.7^{b}$ \\
\hline BWG & $42.92 \pm 9.4^{\mathbf{b}}$ & $24.0 \pm 6^{\mathrm{c}}$ & $42.98 \pm 4.2^{\mathrm{b}}$ & $34.05 \pm 4.2^{\mathrm{ab}}$ & $36.31 \pm 3.6^{b c}$ & $34.92 \pm 5.8^{\mathrm{b}}$ & $35.72 \pm 4.85^{\mathrm{b}}$ & $31.31 \pm 3.2^{\mathrm{bc}}$ \\
\hline
\end{tabular}

* Data are presented as means $\pm \operatorname{SDM}(n=8)$.

Data in a row with different superscript letters are statistically different $(P \leq 0.05)$

IBW= Initial body weight; $\quad$ FBW= Final body weight $\quad$ BWG= Body Weight gain 
Chemical and biological effects of some mixtures of plant oils and Thymus vulgaris on liver diseases

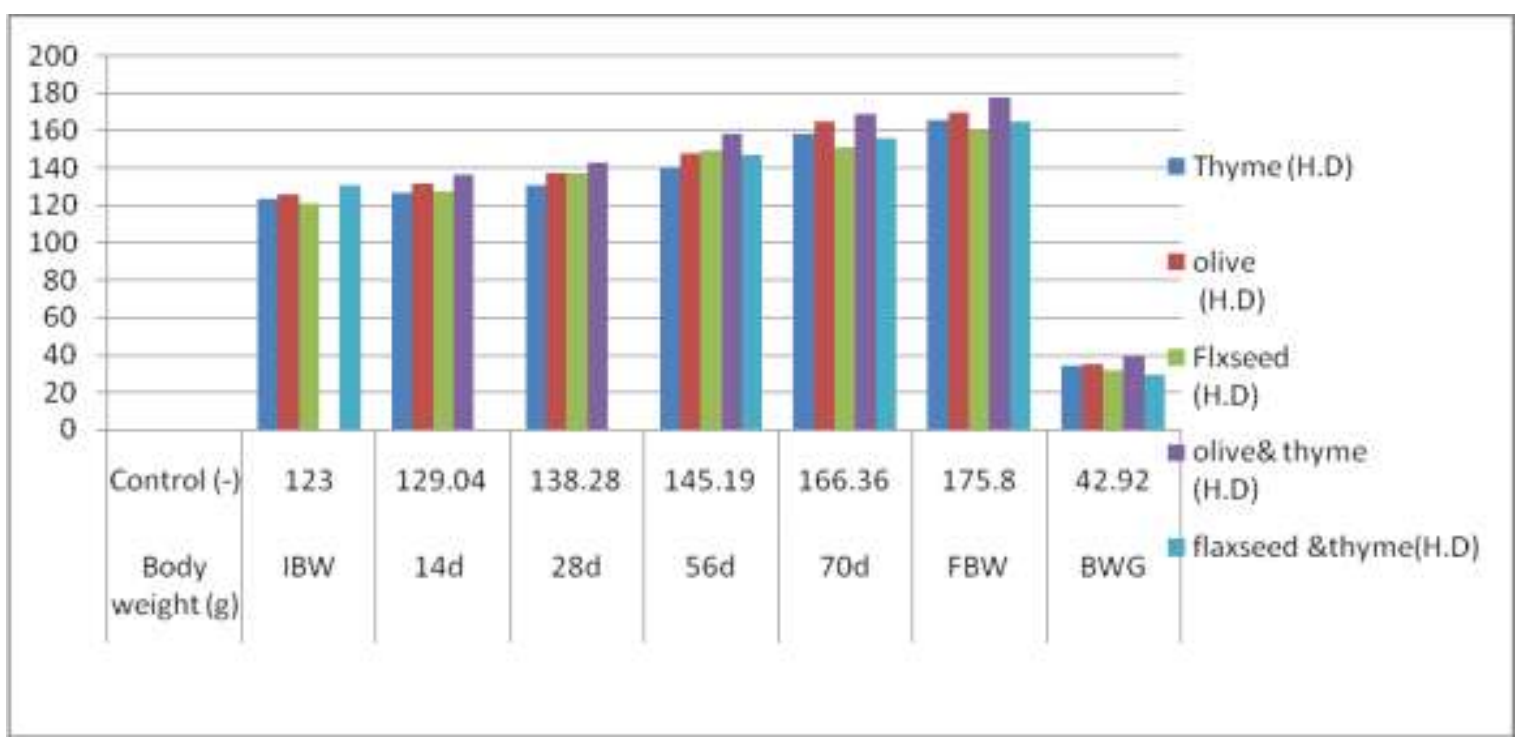

Fig. (1). Body weight gain of rats fed by thyme, olive and flaxseed oil high doses.

Body weight change is often a very sensitive indicator of animal well being. And it integrates with many other parameters and often, in particular, food consumption. The final body weights (FBW) of rats for different groups are given in Table (4) and Figure (1). There were significant differences $(\mathrm{P} \leq 0.05)$ in the final body weights of rats in the control (-) $(175.8 \pm 22.0 \mathrm{~g})$ and the remaining treatment. However, there was no significant difference in animals of group 3 comparing with control (-) group. The lowest rate of body weight gain (BWG) in protected groups (4,6 and 8) and recorded the best result $(34.05 \pm 4.2,92 \pm 5.8$ and $31.31 \pm 3.2 \%$ ) comparing with the control (-) group $(42.92 \%)$, while values for the remaining treated groups $(3,5$ and 7$)$ ranged between $36.31 \pm 3.6 \%$ and $42.98 \pm 4.2 \%$. The lowest rate of body weight gain occurred in control (+) group was $24.0 \%$.

Table (5). Mean organs weight (g) body weight $\%$ of experimental rats treated by different ratios of thyme, olive oil and flaxseed oil.

\begin{tabular}{|l|c|c|c|c|}
\hline Organs weight(g) & Liver $(\mathbf{g})$ & Kidney $(\mathbf{g})$ & Spleen $(\mathbf{g})$ & Heart $(\mathbf{g})$ \\
\hline Control (-) & $2.70 \pm 0.33 \mathrm{~b}$ & $0.79 \pm 0.25^{\mathrm{a}}$ & $0.37 \pm 0.06 \mathrm{~b}$ & $0.32 \pm 0.03 \mathrm{a}$ \\
\hline Control (+) & $2.99 \pm 0.09 \mathrm{a}$ & $0.64 \pm 0.15^{\mathbf{b}}$ & $0.33 \pm 0.06 \mathrm{~b}$ & $0.30 \pm 0.02 \mathrm{~b}$ \\
\hline Group 3 & $2.85 \pm 0.33 \mathrm{~b}$ & $0.71 \pm 0.08^{\mathbf{a b}}$ & $0.45 \pm 0.08 \mathrm{ab}$ & $0.41 \pm 0.09 \mathrm{~b}$ \\
\hline Group 4 & $2.73 \pm 0.23 \mathrm{~b}$ & $0.76 \pm 0.08^{\mathbf{a b}}$ & $0.41 \pm 0.09 \mathrm{ab}$ & $0.39 \pm 0.05 \mathrm{~b}$ \\
\hline Group 5 & $2.70 \pm 0.33^{\mathrm{ab}}$ & $0.79 \pm 0.26^{\mathbf{a}}$ & $0.48 \pm 0.16 \mathrm{a}$ & $0.31 \pm 0.03 \mathrm{a}$ \\
\hline Group 6 & $2.65 \pm 0.29 \mathrm{ab}$ & $0.78 \pm 0.25 \mathrm{a}$ & $0.34 \pm 0.1 \mathrm{ab}$ & $0.30 \pm 0.04 \mathrm{a}$ \\
\hline Group 7 & $2.99 \pm 0.09^{\mathbf{a}}$ & $0.64 \pm 0.15 \mathrm{~b}$ & $0.35 \pm 0.04 \mathrm{ab}$ & $0.31 \pm 0.06 \mathrm{a}$ \\
\hline Group 8 & $1.95 \pm 0.24^{\mathbf{b}}$ & $0.65 \pm 0.08 \mathrm{~b}$ & $0.36 \pm 0.2 \mathrm{ab}$ & $0.31 \pm 0.03 \mathrm{a}$ \\
\hline Group 9 & $2.31 \pm 0.12^{\mathbf{a}}$ & $0.70 \pm 0.07 \mathrm{ab}$ & $0.43 \pm 0.13 \mathrm{a}$ & $0.38 \pm 0.05 \mathrm{~b}$ \\
\hline Group 10 & $2.65 \pm 0.29^{\mathbf{a b}}$ & $0.79 \pm 0.26^{\mathbf{a}}$ & $0.37 \pm 0.06 \mathrm{~b}$ & $0.30 \pm 0.04 \mathrm{~b}$ \\
\hline Group 11 & $2.30 \pm 0.11^{\mathbf{a}}$ & $0.72 \pm 0.06^{\mathbf{a b}}$ & $0.38 \pm 0.05 \mathrm{ab}$ & $0.31 \pm 0.02 \mathrm{a}$ \\
\hline Group 12 & $1.90 \pm 0.23^{\mathbf{b}}$ & $0.79 \pm 0.26^{\mathbf{a}}$ & $0.37 \pm 0.04^{\mathbf{a}}$ & $0.32 \pm 0.03 \mathrm{a}$ \\
\hline
\end{tabular}

* Data are presented as means $\pm \operatorname{SDM}(n=8)$.

Data in a row with different superscript letters are statistically different $(\mathrm{P} \leq 0.05)$ 
Samah M. Ismael et al.

The weights of various organs/body weight $\%$ of rats are shown in Table (5) . The weights of the organs (liver, kidney, spleen and heart) of rats maintained on experimental diets $(+)$ thyme powder substitution of fiber $10 \%$ (group 3) were $(2.85 \pm 0.33,0.71 \pm 0.08, \quad 0.45 \pm .08$ and $0.41 \pm 0.09 \mathrm{~g}$ ), while thyme substitution of fiber for $15 \%$ (group 4) were $(2.73 \pm 0.23$, $0.76 \pm 0.08,0.41 \pm 0.09$ and $0.39 \pm 0.05 \mathrm{~g}$ ) and olive oil for $7 \mathrm{mg}$ in group 5 were $(2.70 \pm 0.33,0.79 \pm 0.26,0.48 \pm 0.16$ and $0.31 \pm \quad 0.03 \mathrm{~g}), \quad$ respectively. Flaxseed oil for $7 \mathrm{mg}$ (group 7) were $(2.99 \pm 0.09, \quad 0.64 \pm 0.15, \quad 0.35 \pm 0.04$ and $0.31 \pm 0.06 \mathrm{~g}$ ), while for $10 \mathrm{mg}$ (group 8) were $(1.95 \pm 0.24,0.65 \pm 0.08,0.36 \pm 0.2$ and $0.31 \pm 0.03 \mathrm{~g})$. In injected groups with $\mathrm{CCl} 4$, there was almost significant difference in the weight of liver, kidney, spleen and heart of rats from control $(+)$ groups. The remaining 3 treatments (injected group) were either show ratio of weight change or suffered a weight loss in liver comparing with control (+).

\section{Biochemical analysis}

Results of biochemical analysis for all tested groups are presented in Table (6). Alterations in the liver enzyme (ALT and AST) were statistically significant $(\mathrm{P} \leq$ $0.05)$ in all tested groups. The results demonstrated that ALT and AST levels in the positive control group $(+)$ recorded a significant increase $(\mathrm{P} \leq 0.05)$ in the activities of serum ALT and AST $(15.37 \pm 1.48$ and $33.67 \pm 3.21 \mathrm{mg} / \mathrm{dl})$ as compared to the negative control group (-) $(9.33 \pm 1.52$ and $17.52 \pm 2.47 \mathrm{mg} / \mathrm{dl})$. While the protected samples (thyme \& olive oil and flaxseed oil) showed different ratios of decrease in serum AST and ALT enzyme compared to the control (+) group (Table (6) and Figure (2).

Table (6). Liver and kidney function of experimental rats treated by different ratios of Thyme, Olive oil and flaxseed oil.

\begin{tabular}{|l|l|l|}
\hline Parameters & $\begin{array}{l}\text { ALT } \\
(\mathbf{U} / \mathbf{L})\end{array}$ & $\begin{array}{l}\text { AST } \\
(\mathbf{U} / \mathbf{L})\end{array}$ \\
\hline Control (-) & $9.33 \pm 1.52^{\mathbf{c}}$ & $17.52 \pm 2.47 \mathrm{c}$ \\
\hline Control (+) & $15.37 \pm 1.48^{\mathbf{a}}$ & $33.67 \pm 3.21^{\mathbf{a}}$ \\
\hline Group 3 & $12.34 \pm 0.55^{\mathbf{a}}$ & $29.55 \pm 2.79^{\mathbf{a}}$ \\
\hline Group 4 & $10.50 \pm 0.58^{\mathbf{a}}$ & $25.58 \pm 4.69^{\mathbf{b}}$ \\
\hline Group 5 & $11.30 \pm 0.42^{\mathbf{b}}$ & $27.70 \pm 1.82^{\mathbf{b}}$ \\
\hline Group 6 & $9.32 \pm 1.62^{\mathbf{c}}$ & $9.32 \pm 1.62^{\mathbf{c}}$ \\
\hline Group 7 & $11.58 \pm 1.68^{\mathbf{a}}$ & $11.58 \pm 1.68^{\mathbf{a}}$ \\
\hline Group 8 & $9.90 \pm 0.10^{\mathbf{b}}$ & $9.90 \pm 0.10^{\mathbf{b}}$ \\
\hline Group 9 & $9.32 \pm 1.62^{\mathbf{c}}$ & $9.32 \pm 1.62^{\mathbf{c}}$ \\
\hline Group 10 & $9.02 \pm 0.10^{\mathbf{b}}$ & $8.32 \pm 1.62^{\mathbf{c}}$ \\
\hline Group 11 & $9.90 \pm 0.10^{\mathbf{b}}$ & $23.30 \pm 2.30^{\mathbf{a}}$ \\
\hline Group 12 & $8.32 \pm 1.62^{\mathbf{c}}$ & $15.72 \pm 2.37^{\mathbf{c}}$ \\
\hline
\end{tabular}

*Data are presented as means $\pm \operatorname{SDM}(n=8)$.

Data in a row with different superscript letters are statistically different $(P \leq 0.05)$. AST: aspartate amino transferase, ALT: alanine amino transferase 

on liver diseases

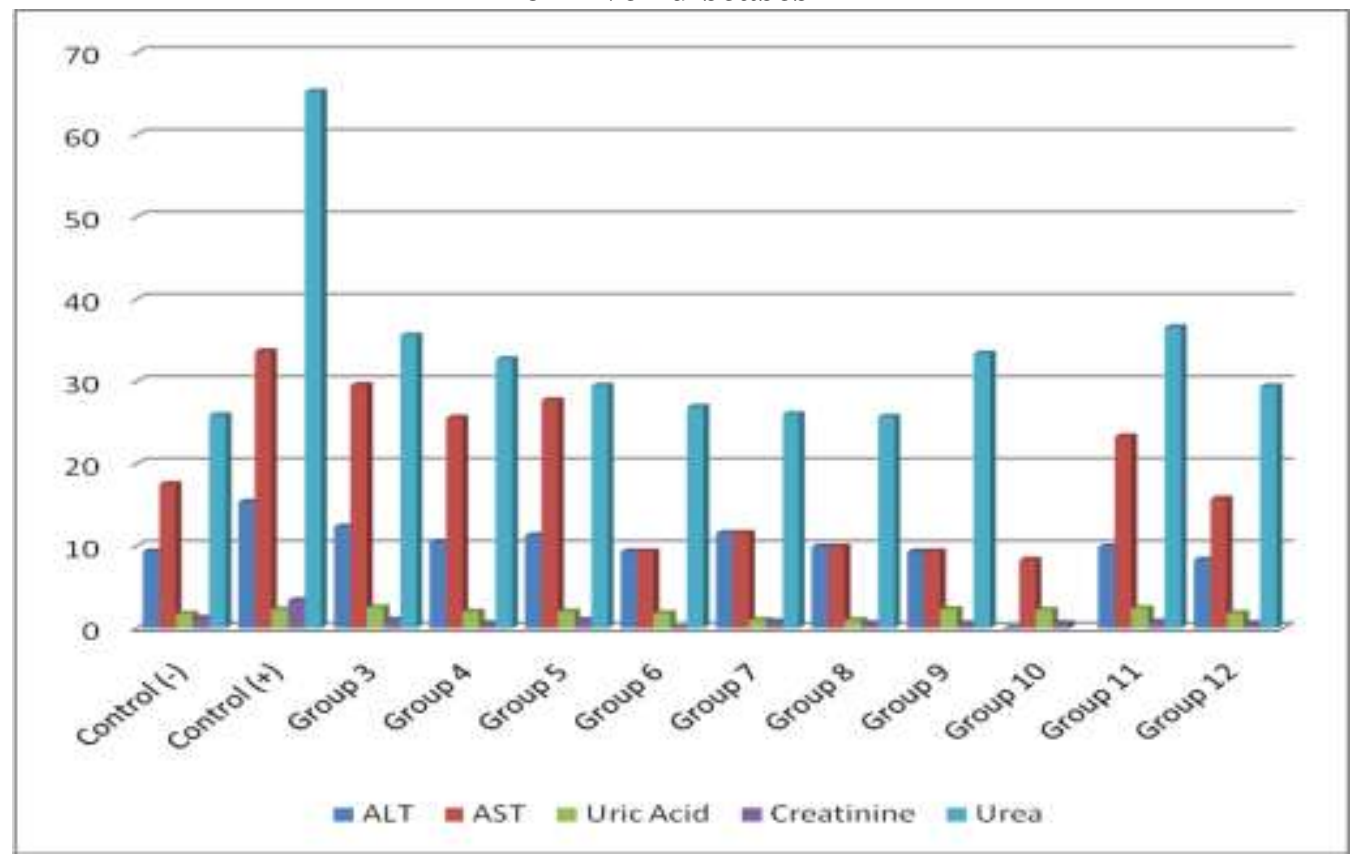

Fig. (2). Effect of different ratios of Thyme, Olive oil and flaxseed oil on Liver and Kidney function of experimental rats

The serum levels of ALT, AST, and GGT reflect the physiological state of the liver; they are changed according to the distortion of liver, resulting from cellular injury of the organ caused by toxic metabolites and diseases (Girish et al., 2019). Results of Parmar et al. (2010) indicated that $\mathrm{CCl}_{4}$ caused an increase in serum levels of the diagnostic enzymes (ALT, AST and GGT) in rats that received $\mathrm{CCl}_{4}$ as compared to the control group.

Ozkol et al. (2015) found that $\mathrm{CCl}_{4}$ induced liver damage, there is an excessive lipid peroxidation leading to functional and structural disruption. The damage or death of hepatocytes usually results in the leakage of the enzymes in the affected tissue into the blood stream (Lee et al., 2018).

Some bioactive compounds of thyme are very effective such as tinnins, steroids and alkaloids. Specific steroids and flavonoids are responsible to protect the liver from oxidative stress and play a key role in hepatoprotection (Joseph, and Raj, 2010). Olive oil possesses hepatoprotective activity and reduces the level of ALT (Nayak et al., 2011)
The present results demonstrated that ALT and AST levels were significantly lower in groups injected with $\mathrm{CCl}_{4}$ compared with control (+) group. Increased serum creatinine above normal levels may reflect destroy of $50 \%$ of renal nephron (Girish et al., 2019).

\section{Lipid profile of rats fed on different ratios of thyme, olive oil and flaxseed oil.}

Results of lipid profile analysis for all tested groups are presented in Table (7) and Figure (3). The results demonstrated significant increase $(p \leq 0.05)$ in the values of cholesterol, triglycerides, HDL-c and LDL-c in control positive group comparing with other treatments in protected and injected groups. It was obvious from Table (7) and Figure (3) that the highest decrease in lipid profile and triglycerides was in groups 4,6 and 8 which recorded $91.60 \pm 15.57,88.90 \pm 38.08$ and $92.60 \pm 38.08 \mathrm{mg} / \mathrm{dl}$ comparing with control (+) $99.50 \pm 14.70 \mathrm{mg} / \mathrm{dl}$ in protected group. This result agreed with Rota et al. (2017) who found that Triglycerides concentrations were significantly decreased in serum of $\mathrm{CCl}_{4}$ treated 
Samah M. Ismael et al.

animals. $\mathrm{CCl}_{4}$ induced a slight decrease in cholesterol levels, which was partially recovered after administration of thyme tincture. The intake of thyme preparations alone did not affect significantly the metabolic function of the liver. Impaired excretory function of the liver was observed after treatment of animals with $\mathrm{CCl}_{4}$. The result in Table (7) showed that Cholesterol recorded high concentration in groups 4,6 and 8 ( $84.50 \pm 5.51,79.60 \pm 7.05$ and $85.60 \pm 7.05 \mathrm{mg} / \mathrm{dl}$, respectively) comparing with control $(+)(89.70 \pm 13.29$ $\mathrm{mg} / \mathrm{dl})$. LDL-c levels in groups (4,6 and 8) were $20.76 \pm 5.86, \quad 18.48 \pm 5.69$ and $18.48 \pm 9.79 \mathrm{mg} / \mathrm{dl}$, respectively comparing with control (+) group (25.09 \pm 12.36 $\mathrm{mg} / \mathrm{dl}$ ). Farooq et al. (2015) showed that the supplementation of olive oil decreases the serum triglycerides, normalizes the liver enzyme biomarkers and significantly reduces the fat droplet accumulation in liver by suppressing the inflammation and restoring the abnormal lipid metabolisms in experimental animals.

Table (7). Lipid profile of experimental rats treated by different ratios of Thyme, Olive oil and flaxseed oil.

\begin{tabular}{|l|l|l|l|l|}
\hline $\begin{array}{l}\text { lipid profile } \\
\text { (mg/dl) }\end{array}$ & $\begin{array}{l}\text { Cholesterol } \\
(\mathbf{m g / d})\end{array}$ & $\begin{array}{l}\text { Triglycerides } \\
(\mathbf{m g / d l})\end{array}$ & $\begin{array}{l}\text { HDL-c } \\
(\mathbf{m g / d})\end{array}$ & $\begin{array}{l}\text { LDL-c } \\
(\mathbf{m g / d l})\end{array}$ \\
\hline Control (-) & $77.90 \pm 19.44^{\mathrm{cb}}$ & $89.40 \pm 7.40^{\mathrm{c}}$ & $29.80 \pm 6.03^{\mathrm{c}}$ & $10.82 \pm 15.75^{\mathrm{c}}$ \\
\hline Control (+) & $89.70 \pm 13.29^{\mathrm{a}}$ & $99.50 \pm 14.70^{\mathrm{a}}$ & $47.50 \pm 9.65^{\mathrm{ab}}$ & $25.09 \pm 12.36^{\mathrm{a}}$ \\
\hline Group 3 & $86.60 \pm 13.93^{\mathrm{b}}$ & $92.90 \pm 9.81^{\mathrm{b}}$ & $45.80 \pm 3.91^{\mathrm{b}}$ & $22.64 \pm 12.07^{\mathrm{a}}$ \\
\hline Group 4 & $84.50 \pm 5.51^{\mathrm{ab}}$ & $91.60 \pm 15.57^{\mathrm{b}}$ & $46.00 \pm 3.63^{\mathrm{b}}$ & $20.76 \pm 5.86^{\mathrm{b}}$ \\
\hline Group 5 & $83.50 \pm 12.28^{\mathrm{c}}$ & $90.50 \pm 11.31^{\mathrm{ab}}$ & $50.50 \pm 17.87^{\mathrm{a}}$ & $20.28 \pm 10.64^{\mathrm{ab}}$ \\
\hline Group 6 & $79.60 \pm 7.05^{\mathrm{b}}$ & $88.90 \pm 38.08^{\mathrm{ab}}$ & $44.00 \pm 13.86^{\mathrm{a}}$ & $18.48 \pm 5.69^{\mathrm{b}}$ \\
\hline Group 7 & $86.20 \pm 10.29^{\mathrm{a}}$ & $94.40 \pm 4.34^{\mathrm{b}}$ & $48.60 \pm 3.21^{\mathrm{b}}$ & $21.56 \pm 3.32^{\mathrm{b}}$ \\
\hline Group 8 & $85.60 \pm 7.05^{\mathrm{b}}$ & $92.60 \pm 38.08^{\mathrm{ab}}$ & $60.00 \pm 12.86^{\mathrm{a}}$ & $18.48 \pm 9.79^{\mathrm{b}}$ \\
\hline Group 9 & $86.20 \pm 10.29^{\mathrm{a}}$ & $94.40 \pm 4.34^{\mathrm{b}}$ & $48.60 \pm 3.21^{\mathrm{b}}$ & $21.56 \pm 3.32^{\mathrm{b}}$ \\
\hline Group 10 & $80.60 \pm 7.05^{\mathrm{b}}$ & $82.60 \pm 38.08^{\mathrm{ab}}$ & $30.00 \pm 12.86^{\mathrm{a}}$ & $12.48 \pm 9.79^{\mathrm{b}}$ \\
\hline Group 11 & $82.40 \pm 11.28^{\mathrm{c}}$ & $76.80 \pm 14.34^{\mathrm{cb}}$ & $54.40 \pm 16.97^{\mathrm{a}}$ & $18.28 \pm 10.64^{\mathrm{ab}}$ \\
\hline Group 12 & $76.80 \pm 14.34^{\mathrm{cb}}$ & $79.40 \pm 7.50^{\mathrm{c}}$ & $26.60 \pm 5.03^{\mathrm{c}}$ & $10.72 \pm 15.75^{\mathrm{c}}$ \\
\hline
\end{tabular}

* Data are presented as means $\pm \operatorname{SDM}(n=6)$.

Data in a row with different superscript letters are statistically different $(P \leq 0.05)$.

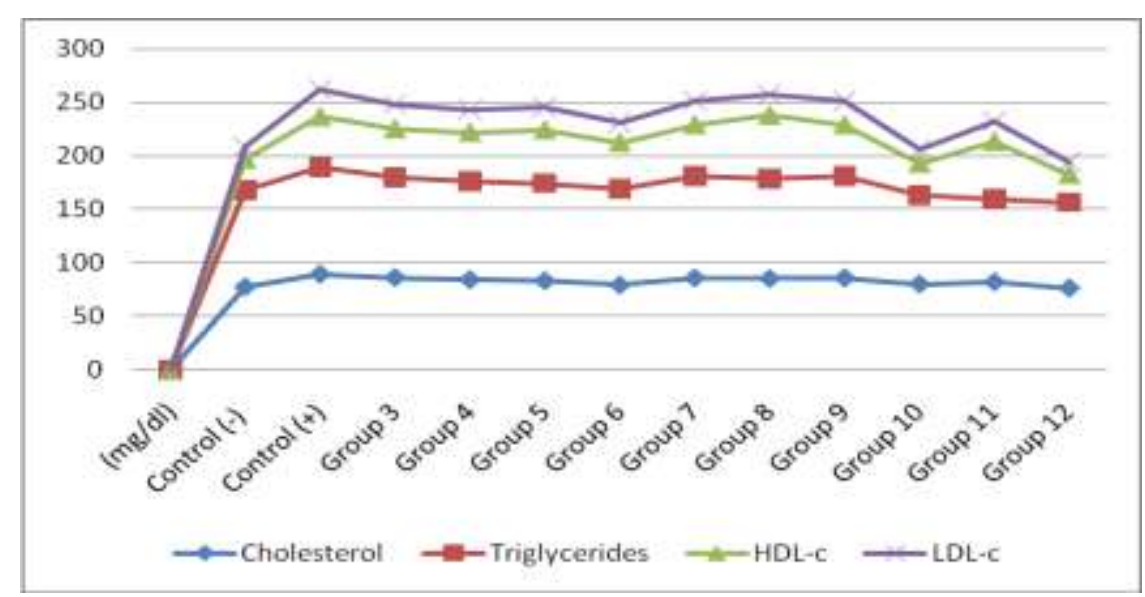

Fig. (3). Effect of different ratios of Thyme, Olive oil and flaxessd oil on lipid Profile of experimental rat

Daun and DeClercq (1994) found that flaxseed oil lowered the total cholesterol by $61 \%$ and increased the proportion in the high density lipoprotein (HDL). Diederichsen and Richards (2015) reported that pre-treatment of rats with 
Samah M. Ismael et al.

flxseed oil significantly reduced the $\mathrm{CCl}_{4}$ induced lipid peroxidation in liver and biochemical changes associated with $\mathrm{CCl}_{4}$. Rašković et al. (2015) evaluated antioxidant activity of thyme preparations and their influence on hepatic function using the hepatotoxicity model induced by $\mathrm{CCl}_{4}$. The pharmaceutical formulations containing thyme may aggravate existing hepatotoxicity. On the contrary, the hepato-protective effects of thyme have been observed in several experimental models of liver injury. The ethanolic and methanolic extracts of thyme have been effective against aflatoxins- and $\mathrm{N}$ nitrosodiethylamine (NDEA)-induced oxidative liver damage (Abdel-Aziem et al., 2014; Noor et al., 2015).

\section{Histopathological examination}

Organs such as liver were examined by a histological approach and the photomicrographs of hematolxylin eosin stained liver is illustrated.

\section{Liver}

The liver was examined by a histological approach and the photomicrographs of hematolxylin. The liver sections from control (-) group (normal rats fed on commercial diet only) showed normal histological structure of the central vein and surrounding hepatocytes in the hepatic parenchyma. There was no histopathological alteration and the normal histological structure of the central vein and surrounding hepatocytes in the parenchyma were recorded in (Fig.4.1). While in control (+) group of experimentally inducted rats by administration of $\mathrm{CCl}_{4}$. Focal lipidosis was observed in the hepatic capsule as well as the underlying hepatocytes in the parenchyma associated with necrosis and degenerative changes in the hepatocytes underneath (Fig.4.2)

Animals fed on thyme $10 \%$ in substitution of fiber, group of experimentally inducted rats and treated by low dose of thyme. The hepatic capsule showed focal lipidosis associated with atrophy in the underlying hepatocytes in the parenchyma were recorded (Fig.4.3) There were oedema and few inflammatory cells infiltration with congestion in the portal vein at the portal area (Fig.4$12 \& 13)$. Rats fed on thyme $15 \%$ in substitution of fiber, group of experimentally inducted rats and treated by $15 \%$ dose of thyme. The portal area showed dilatation in the portal vein as well as periductal inflammatory cells infiltration surrounding the bile ducts (Fig.4.4). Group of experimentally inducted rats and treated by $7 \mathrm{mg}$ dose of olive oil. Sever congestion was observed in the central vein and sinusoids associated with focal hemorrhage in the hepatic parenchyma (Fig.4.5). While group of experimentally inducted rats and treated by $14 \mathrm{mg}$ dose of olive oil showing Few inflammatory cells infiltration was detected in the portal area (Fig.4.6)

Group of experimentally induced rats and treated by $7 \mathrm{mg}$ dose of flaxseed oil The portal area showed few inflammatory cells infiltration (Fig.4.7).While group of experimentally induced rats and treated by $14 \mathrm{mg}$ dose of flaxseed oil .There was no histopathological alteration as recorded in (Fig.4.8). Rats fed on $7 \mathrm{mg}$ dose of olive oil and $10 \%$ thyme .The portal area showed few inflammatory cells infiltration (Fig.9). Group of experimentally induced rats and treated by $14 \mathrm{mg}$ dose of olive oil and $15 \%$ thyme. There was no histopathological alteration as recorded in (Fig.4.10). Group of experimentally induced rats and treated by $7 \mathrm{mg}$ dose of Flaxseed oil and 10\% thyme. Dilatation was observed in the central and portal veins associated with oedema and few inflammatory cells infiltration in the portal area (Fig. 4.11). Group of experimentally induced rats and treated by $14 \mathrm{mg}$ dose of Flaxseed oil and $15 \%$ thyme. There was no histopathological alteration as recorded in (Fig.4.12). 
Chemical and biological effects of some mixtures of plant oils and Thymus vulgaris on liver diseases

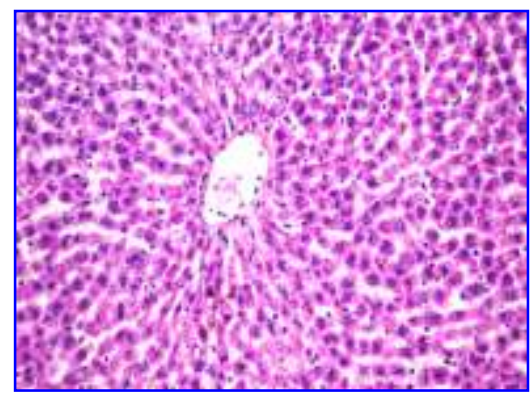

Fig. 4-1 Control (-)

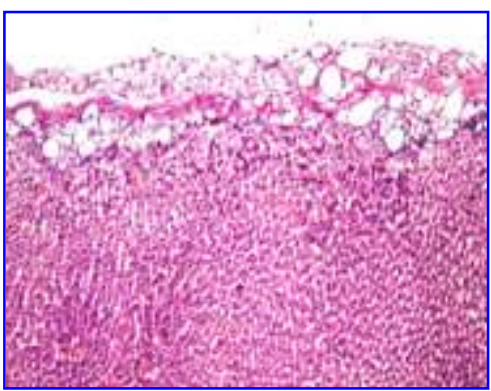

Fig. 4-2 Control (+)

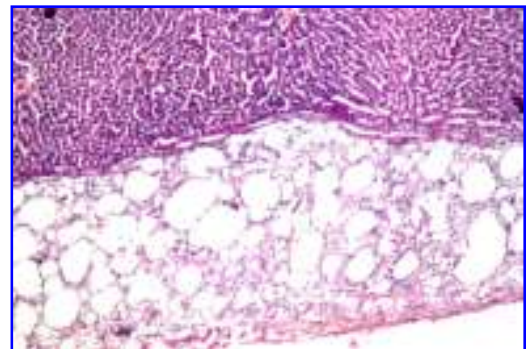

Fig. 4-3.

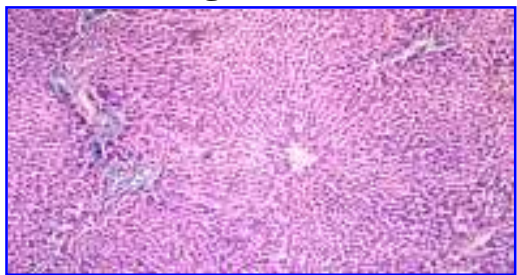

Fig. 4-6

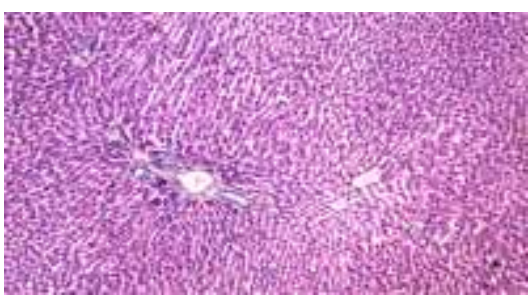

Fig. 4-9

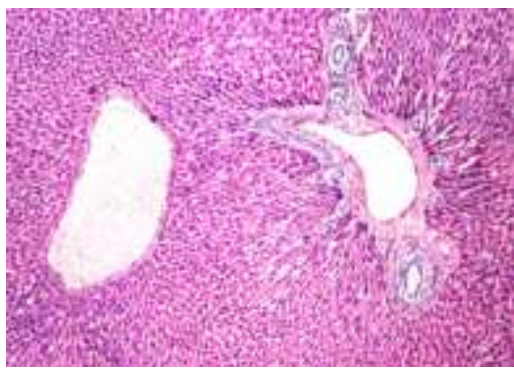

Fig. 4-11

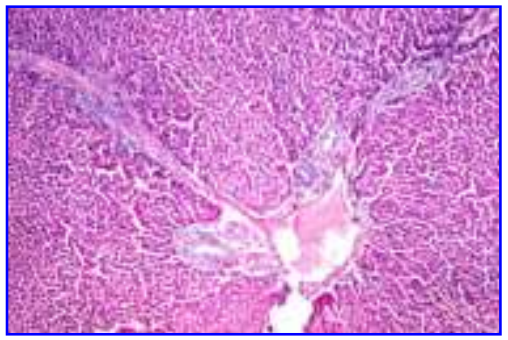

Fig. 4-4

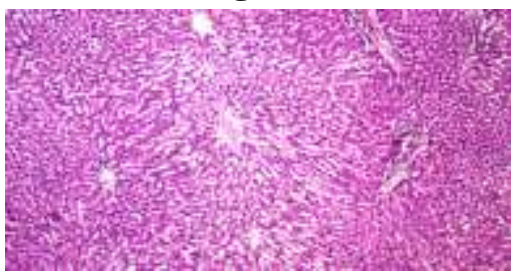

Fig.4-7

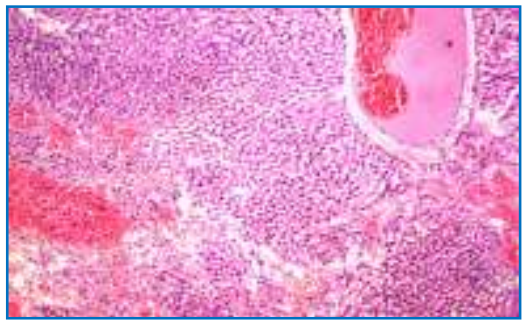

Fig. 4-5

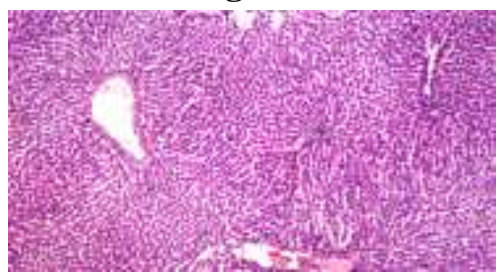

Fig. 4-8

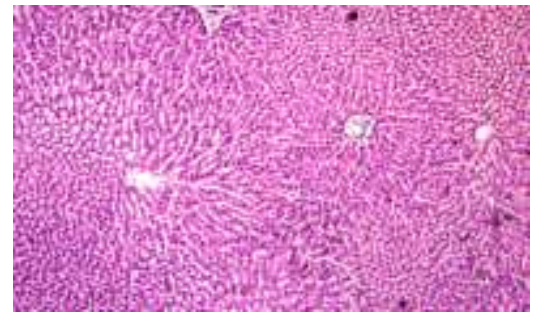

Fig. 4-10

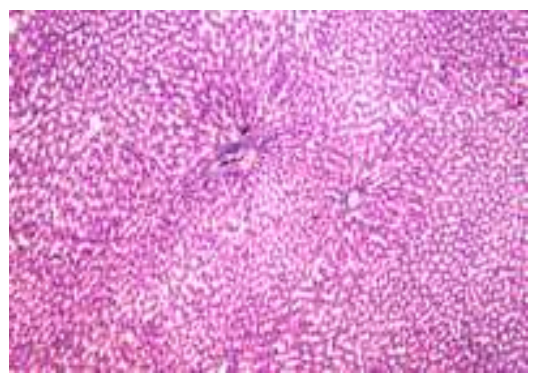

Fig. 4-12

Fig (4): Sections of liver showing histological changes stained with H\&E on using different doses of Thyme, Olive oil and flaxseed oil in protected and injected groups. 
Samah M. Ismael et al.

\section{Legend of Fig. 4.}

Fig. 4-1 Showing normal histological structure of the central vein and surrounding hepatocytes. X40

Fig. 4-2 Showing Focal lipidosis in the capsule as well as with degenerative and necrosis of hepatocytes. X 20

Fig. 4.3 Showing Focal lipidosis in the hepatic capsule with atrophy in the underlying hepatocytes (group 3). X 20

Fig. 4.4 Showing dilatation in the portal vein with few periductal inflammatory cells infiltration surrounding the bile ducts at the portal area (group 4). X 20

Fig. 4 .5 Showing severs congestion in the central vein and sinusoids with focal hemorrhage in the hepatic cells (group 5). X 20

Fig. 4-6 Showing few inflammatory cells infiltration in the portal area (group 6). X 20

Fig. 4-7 Showing few inflammatory cells infiltration in portal area (group 7). X 20

Fig. 4-8 Showing normal histological structure (group 8). X 20

Fig. 4-9 Showing few inflammatory infiltration cells in portal area (group 9). X 20

Fig. 4-10 Showing normal histological structure (group 10). X 20

Fig. 4-11 Showing dilatation central and portal vein with oedema and few inflammatory cells infiltration in portal area (group 11). X 20

Fig. 4-12 Showing normal histological structure (group 12). X 20

\section{REFERENCES}

Al Badr, N.A. (2016). Effect of thyme powder, extract and oil on carbon tetrachlorideinduced liver injury. J. Am. Sci.,7(3):221-227

Aristatile, B.; Al-Numair, K.S.; Veeramani, C. and Pugalendi, K.V.(2019). Effect of carvacrol on hepatic marker enzymes and antioxidant status in Dgalactosamine-induced hepatotoxicity in rats. Fundam. Clin. Pharmacol., 2019:23:757-765 doi: 10.1111/j.14728206.2009.00721.x

Abdel-Aziem, S.H.; Hassan, A.M.; ElDenshary, E.S.; Hamzawy, M.A.; Mannaa, F.A.; Abdel-Wahhab, M.A.(2014),Ameliorative effects of thyme and calendula extracts alone or in combination against aflatoxinsinduced oxidative stress and genotoxicity in rat liver. Cytotechnology. 2014;66:457.-70 doi: 10.1007/s10616-013-9598-7.

AOAC (2000). Association of Official Analytical Chemists, International, William, H. (ed). $17^{\text {th }}$ ed., Gaithersburg, MD, USA.

Barnes, J.; Anderson, L.A. and Phillipson, J.D. (2017). Herbal Medicines. London: Pharmaceutical Press.

Banchroft, J.D.; Sevens, A. and Turner D.R. (1996). Theory and practice of histological techniques. Fourth ed.
Churchill Livingstone, New York, London, San Francisco, Tokyo.

Balkhy, H.; El-Saed, A.; Sanai, F.M.; Alqahtani, M.; Alonaizi, M. and Niazy, N. (2016). Magnitude and causes of loss to follow-up among patients with viral hepatitis at a tertiary care hospital in Saudi Arabia. J. Infect. Public Health, 10(4):379-87.

Chapman, D.G.; Gastilla, R. and Campbell, J.A., (1959). Evaluation of protein in food I.A. Method for the determination of protein efficiency ratio. Can. J .Biochem. Physiol., 37:679-686.

Chen, Y.Y.; Chiang, S.Y.; Lin, J.G.; Yang, J.S.; Ma, Y.S. and Liao, C.L. (2010). Emodin, aloe-emodin and rhein induced DNA damage and inhibited DNA repair gene expression in SCC-4 human tongue cancer cells. Anticancer Res., 30: 945-51.

Daun, J. K. and DeClercq, D.R. (1994). Sixty years of Canadian flaxseed quality surveys at the Grain Research Laboratory. Proc. of the Flax Institute of the United States. Flax Institute of the United States. Fargo, USA.

Diederichsen, A. and Richards, K. (2015). Cultivated flax and the genus Linnum L.: taxonomy and gerplasm conservation. In: Muir, A.D. and Westcott, N.D. (Eds). Flax, The genus 


\section{Chemical and biological effects of some mixtures of plant oils and Thymus vulgaris on liver diseases}

Linum, p. 22-54. London: Taylor \& Francis.

Fachini, Q.F.C.; Kummer, R.; EstevÃ£o-Silva, C.F.; Carvalho, M.,D.; Cunha, J.M. and Grespan , R. (2012). Effects of thymol and carvacrol, constituents of Thymus vulgaris L. essential oil, on the inflammatory response. Evid. Based Complement Alternat Med. (2012).: $657026 . \quad$ doi: 10.1155/2012/657026.

Farooq, W.; Abdalla, Z.; Albahrawy,AZ, and Shaik, R. (2015). Activity of olive oil (Olea europaea) against high fat dietinduced Nonalcoholic Fatty Liver Disease (NAFLD) in mice. Open J. Pathol., 5: 73-83.

Fassati, P. and Prencipe, L. (1982). Serum triglycerides determined colorimetrically with an enzyme that produces hydrogen peroxide. Clin. Chem., 28: 2077.

Grespan, R.; Aguiar, R.P.; Giubilei, F.N.; Fuso, R.R.; Dami Ã£o, M. and J. Silva, E.L. (2014). Hepatoprotective effect of pretreatment with Thymus vulgaris essential oil in experimental model of acetaminophen-induced injury. Evid Based Complement Alternat Med., 2014:954136.

Gan, L.; Chitturi, S. and Farrell, G.C. (2011). Mechanisms and implications of agerelated changes in the liver: Nonalcoholic Fatty Liver Disease in the elderly. Current Gerontology and Geriatrics Res.,( 2011): 831536. https://doi.org/10.1155/2011/831536

Gülçin, S.; Beydemir; F. Topal; N. Gagua; A. Bakuridze; R. Bayram and A. Gepdiremen (2017). Apoptotic, antioxidant and antiradical effects of majdine and isomajdine from Vinca herbacea Waldst. and kit, J. Enzyme Inhib. Med. Chem., 27: 587-594.

Girish, C.; Koner, B.C.; Jayanthi, S.; Rao, K.R.; Rajesh, B., and Pradhan, S.C. (2019). Hepatoprotective activity of six polyherbal formulations in paracetamol induced liver toxicity in mice. Ind. J. Med., Res.;129(5):569-578.

Jayasekhar, p.; Mohanan, P.V. and Rahinam, k. (1997). Hepatoprotective activity of ethyl acetate extract of Acacia
catechu.Ind. J. Pharmacol., 29:426 428 .

Joseph, B., and Raj, S. J., (2010). Pharmacognostic and phytochemical properties of Aloe vera linn. An overview. Int. J. Pharm. Sci., Rev. Res., 4: 106-110.

Kostas, T.E.; Wilkinson, J.S.; White, A.D. and Cook, J.D., (2016). Optimization of a total acid hydrolysis based protocol for the quantification of carbohydrate in macro algae. J. Algal Biomass Utin., 7(1):21-36.

Kaur, R.; Kaur, M. and Singh Gill, B.(2017). Phenolic acid composition of flaxseed cultivars by ultra-performance liquid chromatography (UPLC) and their antioxidant activities: Effect of sand roasting and microwave heating. J. Food Process. Preserv., 41: e13181

Ivanova S, Rashevskaya T. and Makhonina M. (2011). Flaxseed additive application in dairy products production. Procedia Food Sci 1: 275-280.

Lee, G.P.; Jeong, W.I.; Jeong, D.H.; Do, S.H.; Kim, T.H and Jeong, K.S. (2018). Diagnostic evaluation of carbon tetrachloride-induced rat hepatic cirrhosis model. Anticancer Res., 25(2A):1029-38

Lei, S.; Dan, W.; Lei ,W.; et al., (2017). Nosocomial and community-acquired spontaneous bacterial peritonitis in patients with liver cirrhosis in China: Comparative Microbiology and Therapeutic Implications. Sci Rep.; 7: 46025 .

López, Z.; Jinez, G.N.; Navarro, G.A.; Rivera, G.; Flores, J.S.; Ramírez, J.A.; Gutiérrez, B.A. and Knauth, P. (2017). Antioxidant and Cytotoxicological effects of Aloe era food supplements. J. Food Quality, 7(3): 1-10.

Masterton, G.S.; Plevris, N. and Hayes, C. (2017). Omega-3 fatty acids-A promising novel therapy for nonalcoholic fatty liver disease. Aliment. Pharmacol. Ther., 31: 679-692.

Madukwe, E.U.; Ezeugwu, J.O. and Eme, P.E. (2013). Nutrient composition and sensory evaluation of dry Moringa oleifera aqueous extract. Int. J. Basic Appl. Sci., 1:13(3):100-103. 
Samah M. Ismael et al.

Nayak, V.; Gincy, T.B.; Prakash, M.; Joshi, C.; Soumya, S.; Somayaji, S.N.; Madhav, N.V. and Bairy, K.L. (2011). Hepatoprotective activity of Aloe vera Gel against paracetamol induced hepatotoxicity in albino rats. Asian J. Pharm. Biol., Res.; 1:94-98.

Nawal, A. A. J. (2011). Effect of thyme powder, extract and oil on carbon tetrachloride-induced liver injury. Am. Sci.,7(3) Food Sciences and Nutrition Dept,Faculty of Food Science and Agriculture,King Saud

Noor, H.; Ahmed, R.; Abu-Raghi F.; Ban, J. and Hayder, S. (2014).The protective effects of Thymus vulgaris aqueous extract against methotrexate-induced hepatic toxicity in rabbits. Int. J. Pharm. Sci. Rev. Res., 29(2): 187-193.

Ozkol, H.; Tuluce, Y.; Dilsiz, N. and Koyuncu, I. (2015). Therapeutic potential of some plant extracts used in Turkish traditional medicine on streptozocin-induced type 1 diabetes mellitus in rats. J Membr Biol., 2015:246:47.-55 doi: 10.1007/s00232012-9503-X.

Pankaj, K.S.; Deen, D.G.; Ritu, S.; Priyanka, P.; Sharmistha, G.; Atul, K.S.; Ajay K., and Kapil D. P., (2013). Therapeutic and Medicinal Uses of Aloe Vera. Pharmacol. \& Pharmacy, 4: 599-610.

Paoulomi, C.; Aniruddhaa, M. and Subhangkar, N. (2012). Protective effects of the aqueous leaf extract of Aloe barbadensis on gentamicin and cisplatin-induced nephrotoxic rats. Asian Pacific J. Tropical Biomed.,1745-51763.

Parmar, S.R.; Patel, H.V. and Kiran, K. (2010). Hepatoprotective activity of some plants extracts against paracetamol induced hepatotoxicity in rats. J. Herbal Med. Toxicol., 4: 101-106.

Rašković, R.; Pavlović, N.; Kvrgić, M.; Sudji, J.; Mitić, G.; Čapo, I.; and Mikov, M. (2015). Effects of pharmaceutical formulations containing thyme on carbon tetrachloride-induced liver injury in rats. BMC Complementary and Alternative Medicine, 15:441.

Rota, M.C.; Herrera, A.; Martínez, R.M.; Sotomayor, J.A. and Jord'an, M.J. (2018). Antimicrobial activity and chemical composition of Thymus vulgaris, Thymus zygis and Thymus hyemalis essential oils. Food Control,19: 681-7.

SPSS (1998). Statistical Package for Social Science. Computer Software, Ver. 18. SPSS Company, London, UK.

SAS Program, (2006). SAS/STAT User's Guide Release 6.12 edition. Cary, NC, USA: SAS Inst. Inc.

Schermer, S. (1967). The Blood Morphology of Laboratory Animals. $3^{\text {rd }}$ ed., F.A. Davi. Co. Philadelphia, pp: 42-48.

Singh, K.; Mridula, D.; Rehal, J. and Barnwal, P. (2011). Flaxseed- a potential source of food, feed and fiber. Crit. Rev. Food Sci. Nutr., 51:210-222.

Topal, S.B.; Oztürk Sarikaya; E. Bursal; A.C. Gören and M. Bilsel (2018). Polyphenol contents and antioxidant properties of medlar (Mespilus germanica L.), Rec. Nat. Prod., 5: 158-175.

Tietz, N.W.E.D. (1990). Clinical Guide to Laboratory Tests . $2^{\text {nd }}$ ed, Philadelphia : WB Saunders :556

Wani, F.; Abdalla, Z.; Albahrawy, A. and Rahiman, S. (2015). Hypolipidemic activity of olive oil (Oleaeuropaea) against high fat diet-induced nonalcoholic fatty liver disease (NAFLD) in Mice. Open J. Pathol.,5:73-83.

Yousef, M.I.; Omar, S.A.; El-Guendi, M.I. and Abdelmegid, L.A. (2010). Potential protective effects of quercetin and curcum in on paracetamol- induced histological changes, oxidative stress, impaired liver and kidney functions and haematotoxicity in rat. Food Chem. Toxicol., 48: 3246-3261.

WHO (2018). Hepatitis C [Fact sheet]. Retrieved from http:// www.who.int/news-room/factsheets/detail/hepatitis-C. 

on liver diseases

\author{
التأثيرات الكيميائية والبيولوجية لخليط من الزيوت النباتية والزعتر البري على أمراض الكبا

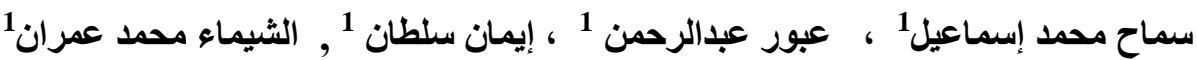

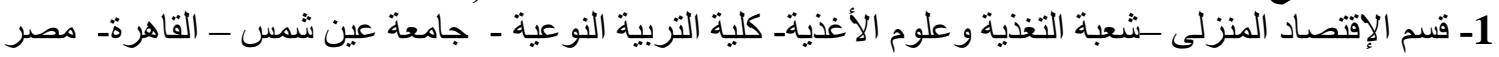 \\ 2- قسم الغدد الصماء و التمثنيل الغذائي ، المعهد القومي للتغذية التية
}

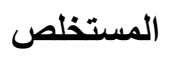

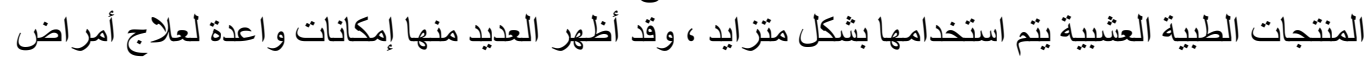

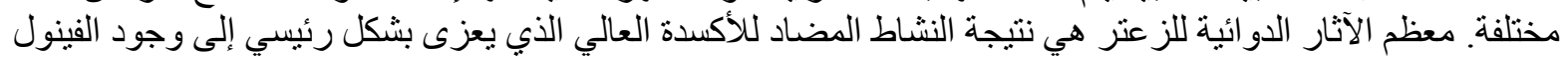

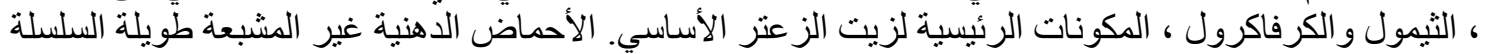

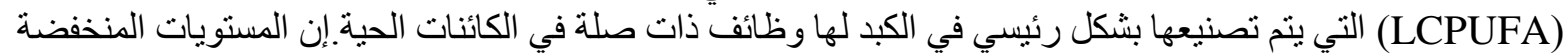

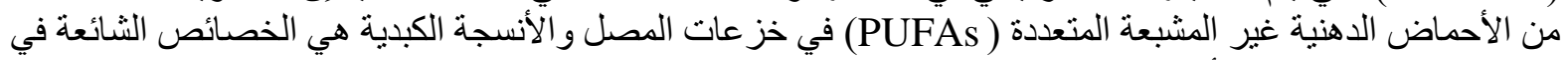

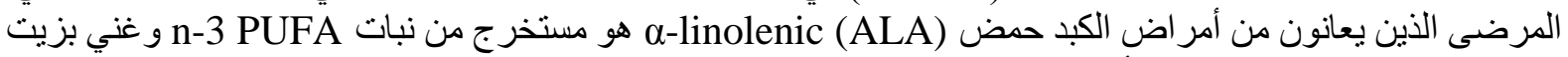

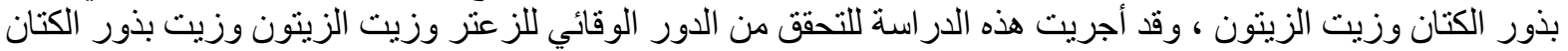

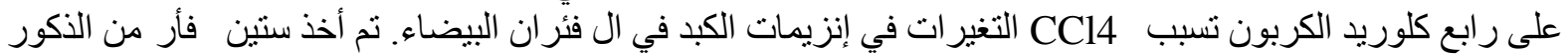

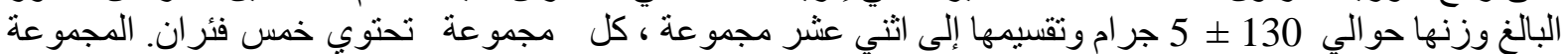

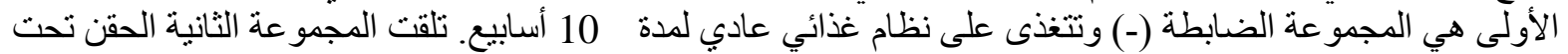

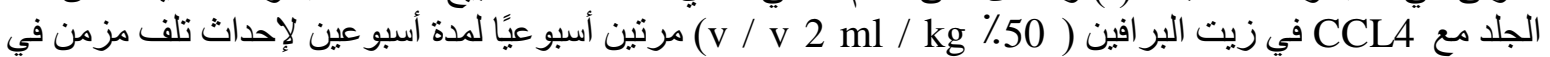

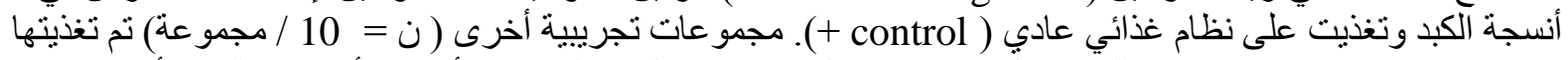

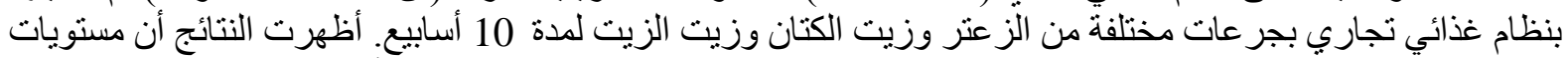

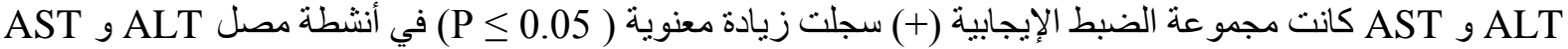

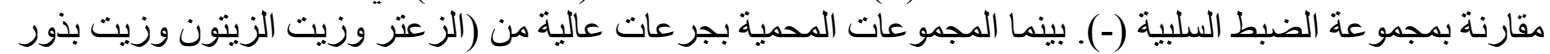

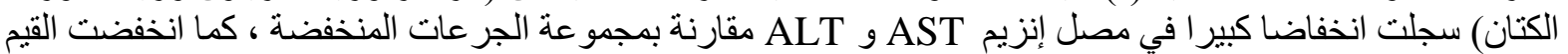

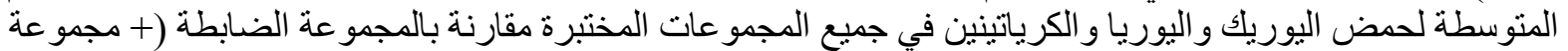

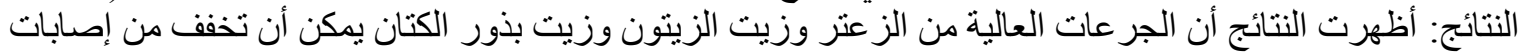

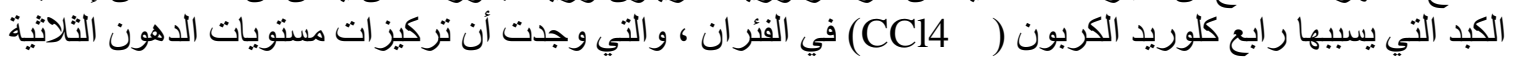

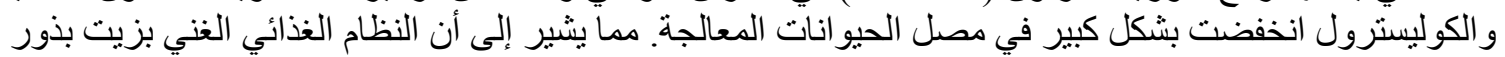

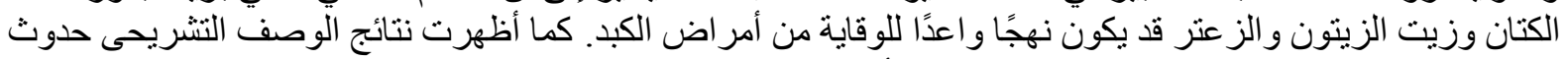

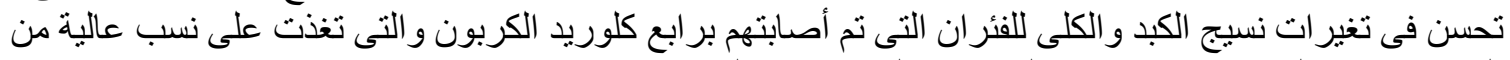
الزعتر وزيت الزيتون وزيت بذور الكتان فى المجمو عات الونئ الوقائية. 